\title{
SISTEM TATA KELOLA PEMERINTAHAN NAGARI DALAM MENDIPTAKAN PUBLIC VALUE DI NAGARI SUNGAI NYALO IV KOTO MUDIEK, KECAMATAN BATANG KAPAS, KABUPATEN PESISIR SELATAN, SUMATERA BARAT
}

\author{
Annisa Aulia Putri 1, Ria Ariany 2, Syamsurizaldi 3 \\ 1, 2, 3 Universitas Andalas, Padang - Sumatera Barat, Indonesia \\ Email: ${ }^{1}$ annisaau5@gmail.com; ${ }^{2}$ riaariany@gmail.com; ${ }^{3}$ syamsurizaldi@gmail.com
}

Article Histori:

Submited: 06/10/2018

Review: 30/10/2018

Editing: 25/4/2019

Publish: 29/04/2019

\section{Abstract}

Nagari Sungai Nyalo is one of the Nagari that applies the principles of governance to be able to advance the development of Nagari, and the welfare of the Nagari community. So, the community will be encouraged to participate in the governance process in Nagari. This research is aim to describe Local Governance Achievers in Sungai Nyalo IV Koto Mudiek Village, Batang Kapas District, Pesisir Selatan Regency. The research method used is qualitative with interview and documentation data collection techniques. Descriptive research type. The results showed that even though Nagari Sungai Nyalo IV Koto Mudiek won the Nagari Achievement competition, however, Governance was still not very good. This can be seen from (1) Accountability, the Government of Nagari Sungai Nyalo IV Koto Mudiek has interacted with the community at the decision making stage, but the socialization of the decision is still lacking (2) Transparency, the Government of Nagari Sungai Nyalo has been transparent, but still lacking in the absence of a website Nagari, and financial disclosure are still lacking (3) Participation, Community and Government have interacted well to increase community participation in the implementation of the Nagari Government.

Keyword: Local, Governance, Achievers

\section{PENDAHULUAN}

Undang-Undang Nomor 6 tahun 2014 tentang desa telah mengembangkan paradigma dan konsep baru tata kelola desa secara nasional. Undang-Undang ini menempatkan Desa sebagai etalase negara, bukan lagi berada di barisan belakang. Lahirnya UU Desa telah mengangkat hak dan kedaulatan desa yang selama ini terpinggirkan karena diletakkan di posisi sub nasional. Pembangunan desa merupakan hal yang sangat penting dilakukan mengingat mayoritas masyarakat Indonesia bermukim di desa (Kurniawan, 2015). 
Pembangunan desa diharapkan dapat meningkatkan kualitas hidup masyarakat desa. Sehubungan dengan hal itu, pembangunan yang dilakukan harus benarbenar menyentuh masyarakat desa. Salah satu alasan pembangunan desa dijadikan fokus Pembangunan Nasional adalah untuk mengurangi kesenjangan antara desa dan kota dengan cara mempercepat pembangunan desa-desa mandiri.

Untuk mendorong percepatan pembangunan dan persaingan sehat antar desa, Pemerintah telah cukup lama melaksanakan program lomba desa berprestasi. Perlombaan ini diatur dalam Permendagri Nomor 13 Tahun 2007 Tentang Perlombaan Desa dan Kelurahan. Mulai tahun 2015, lomba desa diatur dalam Permendagri Nomor 81 tahun 2015 tentang Evaluasi Perkembangan Desa dan Kelurahan. Tujuan dari diadakannya perlombaan desa ini menurut Permendagri Nomor 81 Tahun 2015 tentang Evaluasi Perkembangan Desa dan Kelurahan, pertama adalah untuk menentukan status tertentu dari capaian hasil perkembangan sebuah desa serta untuk mengetahui efektivitas dalam penyelenggaraan pemerintahan, pembangunan, pembinaan kemasyarakatan, dan pemberdayaan masyarakat. Kedua, untuk mengetahui tingkat kesejahteraan masyarakat, daya saing desa yang sesuai dengan nilai-nilai pancasila.

Menurut Permendagri Nomor 81 Tahun 2015, Perlombaan desa adalah evaluasi dan penilaian perkembangan pembangunan atas usaha pemerintah bersama masyarakat desa dan kelurahan yang bersangkutan. Penilaian perlombaan desa dan kelurahan dilakukan dengan membandingkan data tingkat perkembangan desa dan kelurahan dua tahun terakhir berdasarkan data profil desa dan kelurahan sesuai indikator penilaian. Untuk dapat mengikuti perlombaan desa dan kelurahan berprestasi, tahap pertama yang dilakukan adalah desa melakukan evaluasi terhadap dirinya, berdasarkan indikator yang diatur dalam Permendagri Nomor 81 Tahun 2015. Setelah dihitung hasilnya, poin desa diklasifikasikan menjadi tiga kategori, yaitu kurang berkembang, berkembang, dan cepat berkembang. Desa yang berhak mengikuti perlombaan adalah desa dengan kategori berkembang dan cepat berkembang.

Untuk percepatan perkembangan desa pada desa juara dan desa sekitarnya pemerintah provinsi telah merencanakan khusus bagi desa-desa juara lomba desa, akan dijadikan pilot project desa mandiri yang pembinaannya melibatkan seluruh OPD sehingga kegiatannya terkoordinir (Ahfan, Asrori, \& Sipahutar, 2015). Hasil Penelitian Rahmawati Ahfan, Asrori, dan Hotnier Sipahutar tentang Implikasi Juara Lomba Desa pada Perkembangan Desa menunjukkan bahwa desa-desa yang pernah menjadi juara lomba desa mulai mendapat perhatian, yaitu dengan memprogramkan Pilot Project Desa mandiri dengan melibatkan semua SKPD yang dikoordinasikan oleh Bapermasdes tahun 2014-2015 (Ahfan, Asrori, \& Sipahutar, 2015). Hal ini juga salah satu amanat diberlakukannya Undang-Undang Nomor 6 tahun 2014 Tentang Desa, dimana UU ini mengembangkan prinsip keberagaman, mengedepankan azas 
rekognisi, dan subsidiaritas desa. Spirit dari UU ini adalah "desa membangun". UU desa menempatkan desa sebagai subjek pembangunan.

Desa Mandiri merupakan salah satu dari lima tipologi desa yang ditetapkan oleh Kementerian Desa, Pembangunan Daerah Tertinggal dan Transmigrasi (Kemendes PDTT). Desa mandiri memiliki kriteria yang ditetapkan oleh Kemendes PDTT. Kemendes PDTT menetapkan Indeks Desa Membangun (IDM) untuk melihat perkembangan desa, menuju desa mandiri. IDM adalah indeks komposit yang dibentuk dari indeks ketahanan sosial, indeks ketahanan ekonomi, dan indeks ketahanan ekologi desa (Hamidi, 2015). IDM diatur dalam Permendes PDTT Nomor 2 Tahun 2016 tentang Indeks Desa Membangun, yang maksud penyusunannya adalah untuk mendukung upaya pemerintah dalam menangani pengentasan daerah tertinggal dan peningkatan desa mandiri. Sedangkan tujuan penyusunan IDM dalam Permendes PDTT Nomor 2 Tahun 2016 yaitu menetapkan status kemajuan dan kemandirian desa, dan menyediakan data dan informasi dasar bagi pembangunan desa.

Desa mandiri menurut IDM adalah Desa yang telah memiliki kemampuan melaksanakan pembangunan desa untuk peningkatan kualitas hidup dan kehidupan sebesar-besarnya kesejahteraaan masyarakat desa dengan ketahanan sosial, ketahanan ekonomi, dan ketahanan ekologi secara berkelanjutan. Desa yang memiliki kemampuan melaksanakan pembangunan desa dengan kata lain bisa dikatakan telah mampu mengelola desa dengan baik. Mengelola desa dengan baik berarti mengelola sumber daya manusia dan alam. Amanah Undang-Undang Nomor 6 Tahun 2014 Tentang Desa ditujukan agar daerah dalam hal ini Pemerintahan Desa/Nagari harus mampu dan mau mewujudkan kemandirian nagari. Kemandirian bisa didorong dengan membangun hubungan yang selaras dan harmonis dengan masyarakat dan dunia usaha untuk mewujudkan tata pemerintahan yang baik (Syamsurizaldi \& dkk, 2018). Untuk itu, Pemerintah Desa harus mampu berinteraksi dengan masyarakat desa, untuk mengelola sumber potensi desa.

Pemerintah mempunyai tugas mengelola desa untuk kemajuan desa tersebut, dan memunculkan ide-ide serta inovasi baru untuk mengelolanya. Pengelolaan pembangunan yang baik adalah ketika pembangunan tersebut dilakukan bersama-sama dengan masyarakat. Untuk dapat menata dan mengelola desa demi kemajuan desa, diperlukan tata kelola pemerintah desa akan mengantarkan desa menuju percepatan pembangunan, dan untuk mewujudkan desa mandiri.

Salah satu fenomena yang menarik adalah Nagari Sungai Nyalo IV Koto Mudiek, Kecamatan Batang Kapas, Kabupaten Pesisir Selatan memiliki status IDM sebagai desa berkembang. Namun, nagari ini dapat mengalahkan Nagari Manggopoh yang berstatus Nagari Mandiri pada lomba nagari berprestasi tahun 2017. Nagari Sungai Nyalo IV Koto Mudiek 
ditetapkan sebagai Juara 1 nagari berprestasi tingkat Provinsi melalui Surat Keputusan Gubernur Sumatera Barat Nomor 410-574-2017 tentang Penetapan Pemenang Perlombaan Nagari dan Kelurahan Berprestasi Tingkat Provinsi Sumatera Barat Tahun 2017. Untuk menjadi Pilot Project desa mandiri, suatu desa sudah selayaknya menerapkan prinsip tata kelola pemerintahan dalam penyelenggaraan pemerintahannya. Nagari Sungai Nyalo merupakan salah satu Nagari yang menerapkan prinsip-prinsip tersebut, untuk dapat memajukan pembangunan Nagari, dan mensejahterakan masyarakat Nagari. Sehingga, masyarakat akan terdorong untuk ikut dalam proses pemerintahan di Nagari.

\section{METODE}

Penelitian ini bertujuan untuk mendeskripsikan Tata Kelola Pemerintahan Nagari Berprestasi di Nagari Sungai Nyalo IV Koto Mudiek, Kecamatan Batang Kapas, Kabupaten Pesisir Selatan. Penelitian ini menggunakan pendekatan kualitatif dengan jenis penelitian deskriptif. Menurut Bogdan dan Taylor, Penelitian kualitatif merupakan prosedur penelitian yang menghasilkan data deskriptif berupa katakata tertulis dari perilaku orang yang diamati (Moleong, 2010). Peneliti memilih pendekatan ini karena prosedur penelitian yang dilakukan denga cara mengolah datadata berupa tulisan, kata-kata atau lisan dari orang yang ada di lokasi penelitian yang dapat diamati. Tipe penelitian bersifat deskriptif yaitu dengan cara mengumpulkan dan menyusun data kemudian menganalisis dan menginterpretasikannya. Metode deskriptif merupakan prosedur pemecahan masalah yang diselidiki dengan menggambarkan objek penelitian pada saat sekarang berdasarkan fakta-fakta yang tampak atau sebagaimana mestinya (Nawawi, 1994). Pendekatan ini digunakan karena peneliti ingin menjelaskan dan mendeskripsikan bagaimana Peran perantau dalam pelaksanaan pembangunan di Nagari Sungai Puar. Teknik pengumpulan data dalam penelitian ini yaitu wawancara, observasi, dan studi dokumentasi. Pemilihan informan dilakukan dengan menggunakan Purposive sampling. Penelitian ini dilakukan menggunakan empat tahap, yaitu pengumpulan data, interpretasi data, analisis data, dan penarikan kesimpulan. Pada tahap awal peneliti akan mengumpulkan data di lapangan maupun melalui studi literatur. Data yang dikumpulkan adalah data-data yang terkait dengan segala aspek. Selanjutnya data-data ini akan dianalisis dengan teori dan konsep yang digunakan dalam penelitian ini. Selanjutnya menarik kesimpulan.

\section{TATA KELOLA PEMERINTAHAN DESA: TINJAUAN TEORITIK}

Menurut Koiman, Governance merupakan serangkaian proses interaksi sosial politik antara pemerintah dengan masyarakat dalam berbagai bidang yang berkaitan dengan kepentingan masyarakat dan intervensi pemerintah atas kepentingan-kepentingan tersebut (Sedarmayanti, 2004). Pada dasarnya tata kelola pemerintahan mensyaratkan seluruh interaksi yang diambil untuk memecahkan 
masalah sosial dan menciptakan keuntungan atau peluang sosial, dimulai dari perumusan dan penerapan prinsipprinsip yang membimbing interaksi dan kepedulian terhadap lembaga yang memungkinkan dan mengendalikan mereka. Tuntutan governance disini adalah bagaimana masyarakat dilibatkan dalam hal tersebut.

Kekuatan konsep Governance terletak pada keaktifan pemerintah dan masyarakat berinteraksi. Untuk dapat melakukan tata kelola pemerintahan tersebut, diperlukannya prinsip-prinsip yang melandasi tata kelola pemerintahan. Banyak pakar atau ahli mendefinisikan prinsip Governance bervariasi. Namun, menurut Loina Lalolo Krina (Krina, 2003), paling tidak ada sejumlah prinsip yang dianggap sebagai prinsip-prinsip utama Governance, yaitu Akuntabilitas, Transparansi, dan Partisipasi masyarakat.

\section{Akuntabilitas}

Miriam Budiardjo mendefinisikan akuntabilitas sebagai "pertanggungjawaban pihak yang diberi mandat untuk memerintah kepada mereka yang memberi mandat tersebut". Prinsip akuntabilitas publik adalah suatu ukuran yang menunjukkan seberapa besar tingkat kesesuaian penyelenggaraan pelayanan dengan ukuran nilai-nilai atau normanorma eksternal yang dimiliki oleh para stakeholder yang berkepentingan dengan pelayanan tersebut. sehingga dalam tahapan sebuah program, akuntabilitas setiap tahapan (Krina, 2003), yaitu pada tahap proses pembuatan keputusan dan pada tahap sosialisasi kebijakan

\section{Tranparansi}

Transparansi adalah prinsip yang menjamin akses atau kebebasan bagi setiap orang untuk memperoleh informasi tentang kebijakan, proses pembuatan dan pelaksanaannya, serta hasil-hasil yang dicapai (Krina, 2003). Prinsip ini memiliki dua aspek, komunikasi publik oleh pemerintah dan hak masyarakat terhadap informasi. Keduanya akan sulit dilakukan jika pemerintah tidak mengelola kinerjanya dengan baik. Ada tiga karakteristik transparansi menurut Mardiasmo (Lestari, 2013), yaitu informatif, keterbukaan, dan pengungkapan

\section{Partisipasi}

Partisipasi dibutuhkan dalam memperkuat demokrasi dan meningkatkan kualitas dan efektivitas layanan publik. Partisipasi adalah prinsip bahwa setiap orang memiliki hak untuk terlibat dalam pengambilan keputusan di setiap kegiatan penyelenggaraan pemerintahan. Keterlibatan dalam pengambilan keputusan dapat dilakukan secara langsung maupun tidak langsung. Selain itu, juga dilihat dari keterlibatan masyarakat dalam implementasi berbagai kebijakan dan rencana pemerintah, termasuk dalam pengawasan dan evaluasinya. Cohen dan Uphoff (Rosyida \& Nasdian, 2011) membedakan partisipasi menjadi empat jenis, yaitu partisipasi dalam pengambilan keputusan, partisipasi dalam perencanaan, 
partisipasi dalam evaluasi, dan partisipasi dalam pengambilan manfaat.

\section{HASIL DAN PEMBAHASAN}

Tata Kelola Pemerintahan Nagari Sungai Nyalo IV Koto Mudiek

\section{Nagari Sungai Nyalo IV Koto} Mudiek meraih juara 1 lomba Nagari Berprestasi tingkat Provinsi Sumatera Barat pada tahun 2017. Nagari yang baru dimekarkan pada tahun 2011 ini mendapatkan prestasi dengan menonjolkan budaya gotong royong dalam melaksanakan pembangunan Nagari. Nagari Sungai Nyalo IV Koto Mudiek mendapat prestasi karena partisipasi masyarakatnya tinggi. Nagari ini mengembangkan budaya gotong royong dalam melaksanakan kegiatan Nagari. Masyarakat mengembangkan budaya gotong royong untuk memajukan Nagari, sehingga Nagari Sungai Nyalo IV Koto Mudiek mampu memenangkan lomba Nagari Berprestasi. Tata Kelola Pemerintahan merupakan serangkaian proses interaksi sosial politik antara pemerintah dengan masyarakat dalam berbagai bidang yang berkaitan dengan kepentingan masyarakat dan intervensi pemerintah atas kepentingan-kepentingan tersebut. pola interaksi tersebut, juga terjadi di Nagari Sungai Nyalo IV Koto Mudiek, dimana aktor yang melakukan interaksi sosial politik dalam tata kelola Pemerintahan Nagari seperti terdapat pada Tabel berikut ini:

\section{Tabel 1. Aktor Dalam Tata Kelola Pemerintahan Nagari Di Nagari Sungai Nyalo IV Koto Mudiek}

\begin{tabular}{|c|c|c|c|c|}
\hline No & $\begin{array}{c}\text { Ruang } \\
\text { Lingkup }\end{array}$ & State & Private & Community \\
\hline 1 & Nagari & $\begin{array}{l}\text { - Pemerintah Nagari } \\
\text { - Badan Musyawarah } \\
\text { Nagari } \\
\text { - LPMN }\end{array}$ & Bumnag & $\begin{array}{l}\text { - Masyarakat } \\
\text { perantau } \\
\text { - Niniak Mamak } \\
\text { - TP PKK } \\
\text { - Pemuda } \\
\text { - Mahasiswa Unand } \\
\text { - Mahasiswa Unes } \\
\text { - Masyarakat } \\
\text { - } \text { - Penum } \\
\text { - Pendamping Desa }\end{array}$ \\
\hline 2 & Kecamatan & $\begin{array}{l}\text { Pemerintah } \\
\text { Kecamatan Batang } \\
\text { Kapas }\end{array}$ & & \\
\hline 3 & Kabupaten & $\begin{array}{lr}\text { DPMN } & \text { Kabupaten } \\
\text { Pesisir } & \text { Selatan } \\
\text { Pemerintah } & \\
\text { Kabupaten } & \text { Pesisir } \\
\text { Selatan } & \\
\end{array}$ & & \\
\hline 4 & Provinsi & $\begin{array}{l}\text { Pemerintah Provinsi } \\
\text { Sumatera Barat }\end{array}$ & & \\
\hline
\end{tabular}




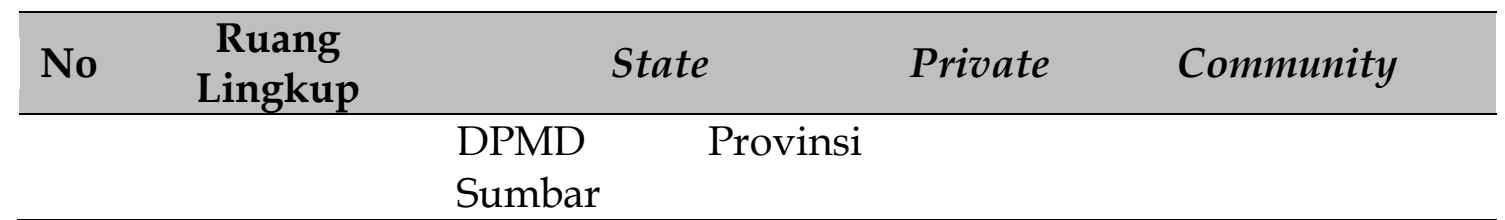

Sumber : Olahan Peneliti, 2018

Tabel diatas memberikan gambaran bahwa yang melaksanakan Pemerintahan Nagari Sungai Nyalo IV Koto Mudiek terdiri dari unsur pemerintahan, Privat, dan kelompok masyarakat, serta masyarakat secara umum. Penyelenggaraan Pemerintahan di Nagari Sungai Nyalo IV Koto Mudiek melibatkan banyak aktor, yang saling berinteraksi untuk menciptakan pemerintahan yang baik. Pemerintah Nagari Sungai Nyalo IV Koto Mudiek berinteraksi dengan kelompok masyarakat, dan Pemerintahan yang lebih tinggi untuk menyelenggarakan Pemerintahan Nagari. Adapun di Nagari Sungai Nyalo IV Koto Mudiek, terdapat tiga kegiatan utama, yaitu penyelenggaraan pemerintahan, pembangunan fisik, dan pemberdayaan masyarakat.

Unsur yang ada dalam Pemerintahan Nagari akan melaksanakan kegiatan pemerintahan sesuai dengan fungsi dan peranannya masing-masing. Dalam pelaksanaan tata kelola pemerintahan, harus ada prinsip yang menjamin tata kelola pemerintahan tersebut berjalan dengan baik, setidaknya ada tiga prinsip dalam penyelenggaraan pemerintahan, yaitu Akuntabilitas, Transparansi, dan Partisipasi. Penelitian ini akan melihat interaksi dari pemerintah dan masyarakat Nagari Sungai Nyalo IV Koto Mudiek dalam melaksanakan tiga program utama pemerintahan, yaitu Penyelenggaraan
Pemerintahan, Pembangunan Fisik, dan Pemberdayaan Masyarakat melalui tiga variabel tata kelola pemerintahan yang dikemukakan oleh Loina Lalolo Krina.

\section{Akuntabilitas}

Pembuatan keputusan di Nagari Sungai Nyalo IV Koto Mudiek melibatkan Pemerintah Nagari, Bamus, Pendamping Desa. kegiatan tersebut dilaksanakan dalam Musyawarah Nagari, untuk menyusun program yang akan dijalankan. Program tersebut dibuat dalam bentuk tertulis di dokumen Rencana Program Kerja (RKP).

Keputusan diambil secara musyawarah, dibuat secara tertulis untuk diserahkan kepada kepala kampung. Pembuatan RKP tersebut dilaksanakan oleh Pemerintah Nagari bersama dengan Bamus, Perwakilan kelompok yang ada di Nagari, dan pendamping desa. Peneliti menganalisis bahwa disini pembuatan keputusan tidak hanya dibuat sendiri oleh Pemerintah Nagari, namun bersama-sama dengan kelompok masyarakat. Pemerintah melakukan interaksi dengan masyarakat untuk membuat program yang akan dijalankan dalam satu tahun. Tujuannya supaya program yang dibuat dapat bermanfaat dan meningkatkan kesejahteraan masyarakat.

Setelah dirumuskan draft rancangan, baru masyarakat melakukan musyawarah di kampung masing-masing bersama dengan kepala kampung. Hal ini untuk 
memusyawarahkan program prioritas yang akan dilaksanakan. Peneliti melihat draft tersebut berbentuk tulisan. Pemerintah Nagari Sungai Nyalo IV Koto Mudiek membuat rancangan RKP dalam bentuk tertulis. Rancangan tersebut diberikan kepada Kepala Kampung masing-masing untuk dibedah, dan dipilih program prioritas yang akan dijalankan. Pencatatan tersebut nanti akan dijadikan bukti bahwa pemerintah dan masyarakat sama-sama berinteraksi dalam menyusun program yang akan dijalankan. Hal ini dimaksudkan supaya masyarakat bisa mengawasi pemerintah, dan pertanggungjawaban pemerintah kepada masyarakat memiliki bukti yang jelas tertulis.

Namun, interaksi pemerintah dengan masyarakat dalam kegiatan pembangunan di Nagari, dinilai masih kurang. Dalam perencanaan, kegiatan yang lebih banyak diusulkan adalah kegiatan pembangunan fisik. Sedangkan pemberdayaan tidak digerakkan. Selain itu, ikatan perantau di Nagari Sungai Nyalo IV Koto Mudiek tidak begitu aktif dalam kegiatan pembangunan di Nagari. Peneliti melihat interaksi pemerintah dengan Perantau dalam hal ini tidak terjalin dengan baik. Dimana perantau tidak terlalu peduli dengan penyelenggaraan pemerintahan di Nagari. Interaksi antara pemerintah dengan perantau pada tahap pengambilan keputusan tidak terjalin dengan baik. Hal ini dikarenakan perantau yang tidak aktif di Nagari.

Dalam proses pembuatan keputusan, Pemerintahan Nagari Sungai Nyalo IV Koto Mudiek tidak menetapkan mekanisme dalam melihat ketercapaian program. Hal ini tentunya berdampak pada interaksi antara pemerintah dengan masyarakat. masyarakat tidak mendapat ruang dan tata cara untuk melihat pertanggungjawaban pemerintah dalam pelaksanaan program. Masyarakat tidak bisa memberikan konsekuensi kepada pemerintah jika standar tersebut tidak terpenuhi. Hal ini karena standar terpenuhi atau tidaknya program tersebut tidak diatur secara rinci. Hal yang ditakutkan nantinya adalah menipisnya kepercayaan masyarakat kepada Pemerintah. Peneliti menyimpulkan untuk tahap proses pembuatan keputusan, Nagari Sungai Nyalo IV Koto Mudiek sudah menerapkan prinsip akuntabilitas, dan Pemerintah bersama masyarakat sudah melakukan interaksi untuk menegakkan prinsip ini. namun pelaksanaannya masih belum secara maksimal.

Sedangkan dalam tahap sosialisasi program, peneliti melihat Pemerintah Nagari Sungai Nyalo IV Koto Mudiek melakukan sosialisasi dari mulut ke mulut, tanpa ada forum khusus untuk mensosialisasikan program yang dibuat. Peneliti melihat tidak adanya sosialisasi yang diberikan oleh Pemerintah Nagari Sungai Nyalo IV Koto Mudiek. Peneliti melihat bahwa pemerintah Nagari Sungai Nyalo IV Koto Mudiek tidak membuat forum khusus untuk mensosialisasikan program yang akan dilaksanakannya. Pemerintah tidak melakukan interaksi dengan masyarakat untuk menyampaikan program. Akibatnya, masyarakat hanya tau pada saat program tersebut akan dijalankan. Sedangkan mereka tidak mendapat informasi rinci. 
Masyarakat Nagari Sungai Nyalo IV Koto Mudiek juga tidak mendapatkan akses untuk mendapatkan informasi dan untuk melakukan pengaduan. Masyarakat berinteraksi dengan Pemerintah, dengan cara masyarakat harus datang langsung ke kantor Wali Nagari untuk mengakses informasi yang akan dicari. Secara keseluruhan, akuntabilitas pada tahap sosialisasi kebijakan, Pemerintah Nagari Sungai Nyalo IV Koto Mudiek masih kurang. Hal ini terlihat dari tidak adanya media untuk penyebarluasan informasi mengenai program yang telah ditetapkan, tidak tersedianya mekanisme pengaduan untuk masyarakat, dan tidak adanya sistem informasi manajemen yang memadai di Nagari Sungai Nyalo IV Koto Mudiek. Peneliti menyimpulkan, secara keseluruhan, interaksi pemerintah dengan masyarakat untuk menerapkan prinsip akuntabilitas belum terlaksana dengan baik. Masih banyak perbaikan yang perlu dilaksanakan untuk dapat meningkatkan akuntabilitas Pemerintah Nagari Sungai Nyalo IV Koto Mudiek.

Jika dilihat akuntabilitas publik di Nagari Sungai Nyalo IV Koto Mudiek, Nagari Sungai Nyalo IV Koto Mudiek sudah menerapkan prinsip akuntabilitas dalam pengambilan keputusan dan sosialisasi keputusan. Namun, penerapan prinsip ini masih mengalami kendala seperti pola pikir yang masih mementingkan pembangunan fisik dibanding dengan peningkatan kemandirian Nagari, sehingga pencapaian RPJM Nagari menjadi tidak maksimal. Selain itu, keterbatasan sosialisasi program yang ditetapkan membuat tidak semua masyarakat mengetahui program tersebut. hal ini menyebabkan terganggunya interaksi antara pemerintah dengan masyarakat dalam menerapakan prinsip ini.

\section{Transparansi}

Dalam program penyelenggaraan pemerintahan, Pemerintah Nagari Sungai Nyalo IV Koto Mudiek menempelkan syarat pelayanan, dan saat akan melakukan pelayanan, Pemerintah Nagari juga menyampaikan apa yang harus dilakukan oleh masyarakat untuk memberikan pelayanan yang mudah. Peneliti melihat Pemerintah Nagari Sungai Nyalo IV Koto Mudiek sudah memberikan informasi rinci terkait syarat pelayanan. Pemerintah Nagari Sungai Nyalo IV Koto Mudiek juga tidak memungut biaya administrasi pelayanan, karena sudah tidak diizinkan lagi. Untuk meningkatkan kepuasan masyarakat, Pemerintah Nagari Sungai Nyalo IV Koto Mudiek memiliki motto pelayanan "secepatnya". Dari wawancara diatas terlihat bahwa Pemerintah Nagari Sungai Nyalo IV Koto Mudiek sudah melaksanakan aturan terkait SOP Pelayanan, dan sudah informatif.

Dalam pada program pembangunan fisik dan pemberdayaan masyarakat, Pemerintah Nagari Sungai Nyalo IV Koto Mudiek juga menerapkan prinsip transparansi. Informasi pembangunan dan pelayanan disediakan kepada masyarakat melalui Kepala Kampung. Selain itu, informasi tersebut bisa dilihat dari APBNagari yang dipajang di Kantor Wali 
Nagari. Namun, Pemerintah Nagari Sungai Nyalo IV Koto Mudiek tidak menyediakan informasi terkait mekanisme dan prosedur. Peneliti menyimpulkan, untuk informatif, Nagari Sungai Nyalo IV Koto Mudiek sudah informatif, namun, masyarakat yang ingin mengakses informasi tersebut harus datang langsung ke kantor wali nagari.

Dari wawancara di atas, dapat disimpulkan bahwa masyarakat Nagari Sungai Nyalo IV Koto Mudiek menerima informasi terkait pembangunan dan pemberdayaan lewat penyampaian dari orang lain. Pemerintah tidak menyediakan informasi terkait program. Hal ini menyebabkan masyarakat yang mengikuti program tersebut hanya terbatas pada masyarakat yang mengetahui saja. Hal ini juga menyebabkan informasi yang disampaikan tidak tersalurkan secara merata. Namun, jika masyarakat membutuhkan informasi, jika berkunjung langsung ke kantor Wali Nagari akan diberikan informasi yang dibutuhkan. Tapi informasi tersebut tidak dipajang.

Dalam bentuk keterbukaan informasi, Nagari Sungai Nyalo IV Koto Mudiek menyediakan website nagari seperti dalam tampilan gambar dibwah ini:

\section{Gambar 1. Tampilan Layanan Digital Nagari}

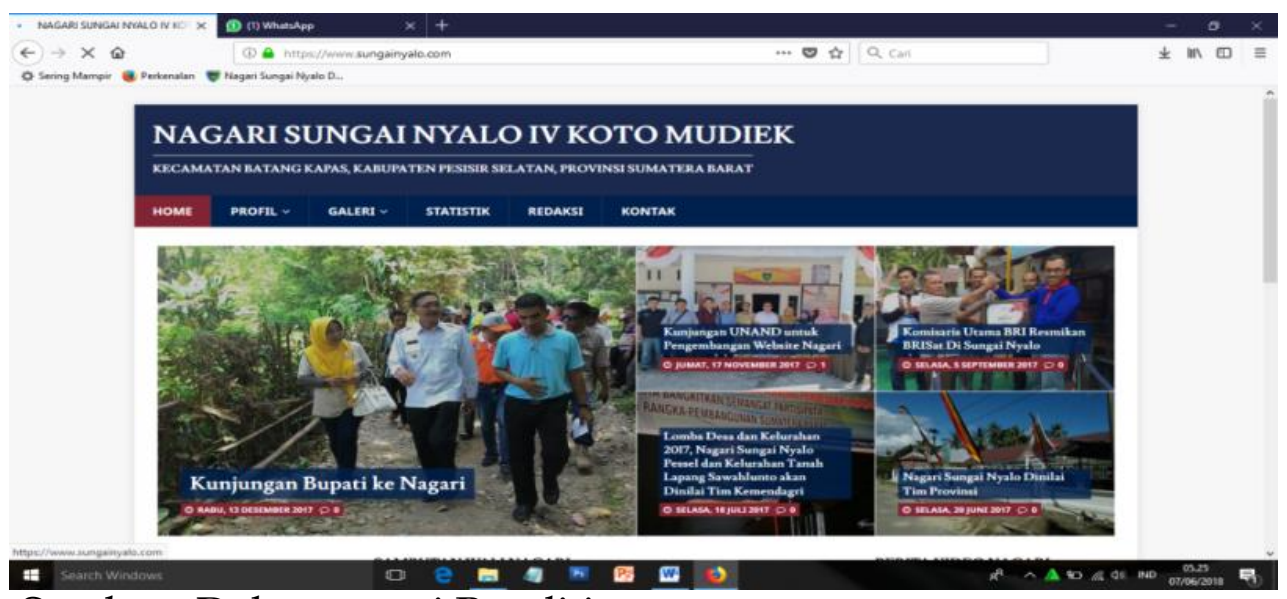

Sumber : Dokumentasi Peneliti

Gambar diatas menunjukkan bahwa Pemerintah Nagari Sungai Nyalo IV Koto Mudiek memiliki website Nagari, dan kegiatan Pemerintah Nagari Sungai Nyalo IV Koto Mudiek dibagikan pada website ini. Namun, jika dilihat lebih dalam, website ini terakhir kali di-update adalah pada tahun 2017. Artinya, website ini tidak lagi aktif dan memberikan informasi terbaru. Hal ini tentu berdampak pada masyarakat di luar Nagari Sungai Nyalo IV
Koto Mudiek, seperti akademisi, terutama perantau yang ingin mengetahui kondisi Nagari. Perantau, akademisi, maupun masyarakat secara luas yang tidak berada di Nagari Sungai Nyalo IV Koto Mudiek tentu ingin mengakses informasi yang ada di Nagari Sungai Nyalo IV Koto Mudiek dengan mudah, cepat, dan Up to Date. Namun, jika website ini tidak aktif, interaksi pemerintah dengan perantau terutama, akan semakin sulit. Karena para 
perantau tentunya tidak melihat kondisi Nagari mereka secara langsung.

Jika dilihat pada website tersebut, tidak ada informasi dasar yang bisa diperoleh publik terkait Nagari Sungai Nyalo IV Koto Mudiek. Pada dasarnya, sebuah website sudah selayaknya menyediakan informasi dasar Nagari di website tersebut. akibatnya, masyarakat maupun publik secara luas tidak bisa mengakses informasi terkait Nagari.

Kerjasama yang dilakukan oleh Pemerintah Nagari Sungai Nyalo IV Koto Mudiek dengan mahasiswa Universitas Andalas merupakan salah satu bentuk interaksi yang dibangun oleh Pemerintah Nagari Sungai Nyalo IV Koto Mudiek dengan pihak luar. Interaksi tersebut berjalan dengan baik, sehingga tercipta suatu website Nagari yang akan mempermudah Pemerintah berinteraksi dengan masyarakat sekitar, perantau, dan masyarakat umum secara luas. Namun, website tersebut tidak dikembangkan, sehingga kondisi Nagari Sungai Nyalo IV Koto Mudiek tidak diungkapkan secara luas. Hanya masyarakat dan pihak yang berkepentingan yang ingin mengakses informasi, bisa mendapatkannya dengan mendatangi kantor Wali Nagari secara langsung.

Sedangkan untuk kondisi keuangan, saat ini Kementerian Keuangan mewajibkan seluruh pemerintah desa untuk menampilkan APB Nagari dalam bentuk spanduk atau banner untuk dapat diakses oleh masyarakat. Nagari Sungai Nyalo IV Koto Mudiek sudah membuat banner untuk APBNagari, namun hanya yang terletak di kantor wali nagari.

\section{Gambar 2. Transparansi Anggaran Nagari}

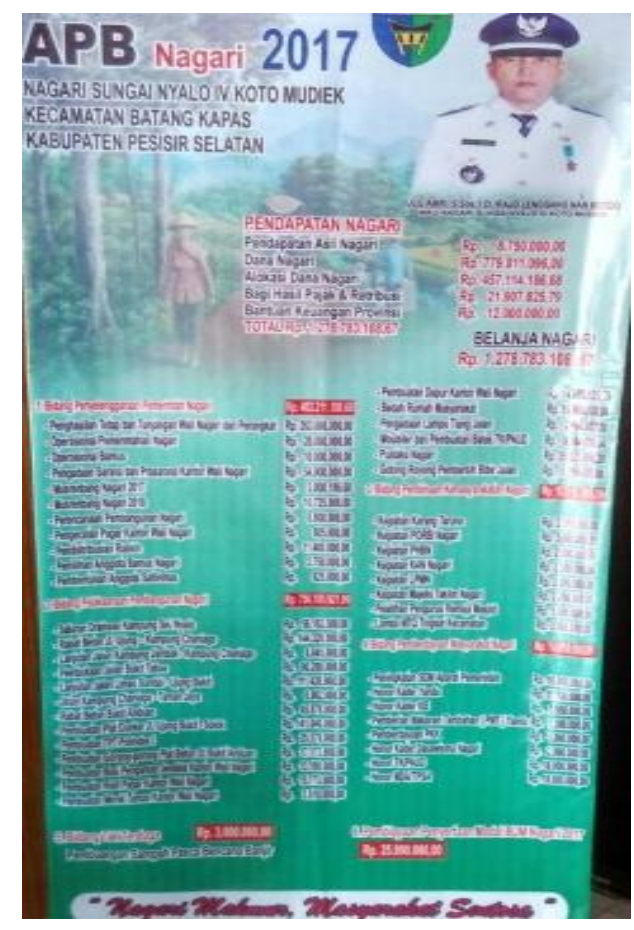

Sumber: Dokumentasi Penelitian

Peneliti menyimpulkan bahwa Pemerintah Nagari Sungai Nyalo IV Koto Mudiek sudah melakukan interaksi dengan masyarakat dalam hal pengungkapan kondisi keuangan. Hal ini bisa terlihat dengan adanya banner APB Nagari yang diletakkan di kantor Wali Nagari. Namun, informasi mendetail tidak diberikan oleh Nagari kepada masyarakat, kecuali masyarakat meminta langsung ke kantor wali nagari.

Secara keseluruhan, untuk prinsip transparansi peneliti menyimpulkan Nagari Sungai Nyalo IV Koto Mudiek sudah menerapkan prinsip transparansi, dimana Pemerintah Nagari Sungai Nyalo IV Koto Mudiek sudah membuat mekanisme, tata cara, dan prosedur untuk mempermudah 
masyarakat, sudah mengungkapkan APBNagari di Banner, dan sudah menempelkan hasil pembangunan. Namun pada beberapa kegiatan masih belum secara maksimal. Hal ini seperti Nagari Sungai Nyalo IV Koto Mudiek masih belum mengelola website dengan benar, kondisi keuangan yang diungkapkan hanya sebatas APBNagari, dan hasil pembangunan yang ditempel tidak diperbarui. Pemerintah Nagari Sungai Nyalo IV Koto Mudiek juga sudah melakukan interaksi dengan masyarakat untuk dapat menerapkan prinsip transparansi ini. Namun, kendala teknis pelaksanaan yang masih perlu diperbaiki untuk semakin mempermudah masyarakat mengetahui kondisi Nagari Sungai Nyalo IV Koto Mudiek, baik dalam hal penyelenggaraan pemerintahan, pembangunan fisik, maupun pemberdayaan masyarakat.

\section{Partisipasi}

Dalam pengambilan keputusan, masyarakat diikutsertakan untuk memilih keputusan yang prioritas bagi mereka. Dalam penyusunan sebuah rancangan RKP, Pemerintah Nagari Sungai Nyalo IV Koto Mudiek mengikutsertakan masyarakat dalam Musyawarah Nagari penyusunan rancangan RKP. Sebelum musyawarah di Nagari, masyarakat akan mengadakan musyawarah di kampung masing-masing untuk menentukan prioritas program.

Masyarakat dilibatkan dalam penentuan keputusan program yang akan dijalankan dalam satu tahun. Program yang akan diajukan adalah program yang sesuai dengan apa yang dibutuhkan oleh masyarakat. hal ini bisa dilihat dari daftar usulan yang diajukan oleh masyarakat (terlampir). Dari daftar usulan tersebut, saat Musrenbang Nagari, akan dipilih program prioritas. Dengan melaksanakan prosedur seperti itu, masyarakat akan merasa bahwa apa yang dibutuhkan mereka didengar dan direncanakan oleh Pemerintah. Hal ini akan meningkatkan partisipasi masyarakat, dan kepercayaan masyarakat terhadap Pemerintah Nagari.

Dalam pelaksanaan, partisipasi masyarakat tergolong tinggi. Dalam program penyelenggaraan pemerintahan, Masyarakat berinteraksi dengan Pemerintah secara langsung dengan mendatangi kantor Wali Nagari. Pemerintah Nagari Sungai Nyalo IV Koto Mudiek melakukan interaksi dengan masyarakat dalam melaksanakan program pemerintahan. Masyarakat diberikan kemudahan akses, dan diberikan pelayanan yang memuaskan supaya masyarakat nyaman berhubungan dengan Pemerintah Nagari.

Dalam program pembangunan fisik dan pemberdayaan masyarakat, Pemerintah Nagari Sungai Nyalo IV Koto Mudiek juga melakukan interaksi dengan masyarakat. Hal ini bisa dilihat pada pelaksanaan pembangunan di Nagari Sungai Nyalo IV Koto Mudiek melibatkan masyarakat sekitar tempat dilaksanakan pembangunan. Namun, dari dua bentuk program pemerintah tersebut, Pemerintah Nagari lebih berfokus pada pembangunan fisik. Walaupun demikian, dalam pelaksanaan pembangunan fisik, partisipasi masyarakat tinggi.

Masyarakat Nagari Sungai Nyalo IV Koto Mudiek memiliki budaya gotong 
royong. Dimana masyarakat nagari ikut terlibat dalam pelaksanaan pembangunan. Disini terlihat bahwa interaksi Pemerintah dengan masyarakat nagari terjalin dengan baik. Pemerintah mampu melibatkan masyarakat dalam melaksanakan kegiatan yang ada di Nagari. Nagari Sungai Nyalo IV Koto Mudiek melibatkan masyarakat sekitar secara langsung dalam proses pembangunan. Peneliti melihat bahwa Pemerintah Nagari Sungai Nyalo IV Koto Mudiek memiliki strategi dengan mengajak masyarakat sekitar untuk melaksanakan pembangunan. Nanti Pemerintah Nagari Sungai Nyalo IV Koto Mudiek akan menggaji mereka. Namun, satu dua minggu juga akan dilaksanakan gotong royong untuk membantu pekerja tersebut.

Peneliti melihat bahwa Pemerintah Nagari Sungai Nyalo IV Koto Mudiek mampu meningkatkan partisipasi masyarakat dengan berinteraksi secara intens dengan masyarakat untuk melaksanakan program pemerintahan. Peneliti membagi bentuk partisipasi masyarakat dalam tahap pelaksanaan menjadi dua, yaitu dalam bentuk sumbangan materi dan dalam bentuk sumbangan tenaga. Dalam bentuk sumbangan materi, masyarakat Nagari Sungai Nyalo IV Koto Mudiek tidak menyumbang dalam bentuk uang. Tetapi mereka menyumbang dalam bentuk tanah. Masyarakat Nagari Sungai Nyalo IV Koto Mudiek berpartisipasi secara materi untuk memajukan nagari. Masyarakat dengan sukarela menyumbangkan tanah untuk pembangunan Nagari. Peneliti melihat Pemerintah Nagari Sungai Nyalo IV Koto
Mudiek mampu meyakinkan masyarakat untuk memberikan tanah mereka secara sukarela, tanpa ganti rugi.

Dalam tahap evaluasi, Masyarakat Nagari Sungai Nyalo IV Koto Mudiek ikut berpartisipasi. Pemerintah Nagari Sungai Nyalo IV Koto Mudiek diberikan ruang untuk mengevaluasi hasil kerja Pemerintah Nagari. Tapi, menurut Wali Nagari Sungai Nyalo IV Koto Mudiek, tidak ada keluhan dari masyarakat terkait kerja perangkat Nagari. Peneliti menyimpulkan masyarakat tidak mengadukan keluhan atau evaluasi secara langsung ke Pemerintah Nagari. Hal ini karena Pemerintah Nagari Sungai Nyalo IV Koto Mudiek tidak memberikan mekanisme bagaimana penyampaian evaluasi dari masyarakat secara jelas.

Dalam evaluasi, masyarakat ikut berpartisipasi, namun dengan menyampaikan kepada niniak mamak mereka jika ada yang tidak sesuai dengan yang seharusnya. Nanti niniak mamak lah yang akan menyampaikan permasalahan atau keluhan mereka kepada Nagari. Terlihat disini interaksi yang terjadi antara pemerintah dengan masyarakat pada evaluasi berlangsung antara pemerintah dengan tokoh masyarakat. Masyarakat secara umum tidak memiliki akses untuk menyampaikan keluhan dan evaluasi secara langsung kepada Pemerintah Nagari. Sehingga, mereka menyampaikan lewat tokoh masyarakat seperti niniak mamak, untuk dapat disampaikan kepada Pemerintah Nagari Sungai Nyalo IV Koto Mudiek.

Sedangkan Dalam pengambilan manfaat, partisipasi tidak bisa dilepaskan 
dari hasil yang telah dicapai, baik kualitas maupun kuantitas. Peneliti melihat bahwa kegiatan yang dilaksanakan oleh Nagari, yang disusun di dalam RKP merupakan usulan dari masyarakat. sehingga hasil yang diterima akan sesuai dengan apa yang diharapkan oleh masyarakat. Peneliti menganalisis bahwa dengan hasil yang terlihat langsung oleh masyarakat, akan menambah kepercayaan masyarakat kepada Pemerintah Nagari. Karena itu, partisipasi masyarakat menjadi lebih tinggi. Interaksi pemerintah dengan masyarakat dalam pengambilan masyarakat juga terjalin dengan baik. Dalam program penyelenggaraan pemerintahan, masyarakat merasakan manfaat dari ditempelnya spanduk-spanduk dan banner-banner terkait informasi pelayanan. Hal ini tentunya akan memberikan kemudahan masyarakat untuk mendapatkan pelayanan di Kantor Wali Nagari. Walaupun interaksi sudah baik, namun Pemerintah Nagari Sungai Nyalo IV Koto Mudiek belum mendorong masyarakat untuk berinovasi mewujudkan kemandirian masyarakat. Seharusnya Pemerintah Nagari mampu mendorong masyarakat untuk mampu berfikir lebih terbuka, dan tidak hanya berfokus pada pembangunan fisik. Pada akhirnya, manfaat yang diterima oleh masyarakat akan semakin banyak.

\section{KESIMPULAN}

Berdasarkan penelitian yang telah dilakukan di Nagari Sungai Nyalo VI Koto Mudiek, dan dianalisis menggunakan prinsip-prinsip tata kelola pemerintahan menurut Loina Lalolo Krina yang terdiri dari tiga variabel, yaitu akuntabilitas, transparansi, dan partisipasi, dapat ditarik kesimpulan bahwa Nagari Sungai Nyalo IV Koto Mudiek unggul pada partisipasi, namun perlu peningkatan akuntabilitas dan transparansi.

Masih terdapat beberapa kendala dalam tata kelola pemerintahan Nagari Sungai Nyalo IV Koto Mudiek, terutama dalam hal akses publik. Sebaiknya, Pemerintah Nagari Sungai Nyalo mulai membuat akses informasi lewat elektronik, untuk dapat mempermudah masyarakat mengaksesnya. Terlebih dari itu, dilihat program yang dilaksanakan oleh Nagari didominasi oleh pembangunan fisik, sebaiknya program pemberdayaan masyarakat juga lebih digalakkan lagi, dan Pemerintah Nagari Sungai Nyalo IV Koto Mudiek juga menyusun mekanisme untuk pengaduan masyarakat.

Pemerintah Nagari Sungai Nyalo IV Koto Mudiek perlu meningkatkan interaksinya dengan masyarakat, dengan cara mendorong masyarakat terlibat langsung dan mengawasi jalannya pemerintahan di Nagari Sungai Nyalo IV Koto Mudiek. Dengan meningkatkan interaksi tersebut, akan tercipta tata kelola pemerintahan desa yang baik, dan mampu meningkatkan status Nagari Sungai Nyalo IV Koto Mudiek menjadi Nagari Mandiri.

\section{DAFTAR PUSTAKA}

Ahfan, R., Asrori, \& Sipahutar, H. (2015). Implikasi Juara Lomba Desa pada Perkembangan Desa. Jurnal Bina Praja Vol. 7 No. 4, 299.

Hamidi, H. (2015). Indeks Desa Membangun. Jakarta: Kemendes PDTT. 
Krina, L. L. (2003). Indikator dan Alat Ukur Prinsip Akuntabilitas, Transparansi, dan Partisipasi. Jakarta: BPPD.

Kurniawan, B. (2015). Desa Mandiri Desa Membangun. Jakarta: Kemendes PDTT.

Lestari, N. (2013). Pengaruh Akuntabilitas Publik, Partisipasi Masyarakat, dan Transparansi Kebijakan Publik terhadap Pengawasan Keuangan Daerah (APBD) DPRD Kota Bandung. Bandung: Repository Widyatama.

Moleong, L. (2010). Metodologi Penelitian Kualitatif. Bandung: Remaja Rosdakarya.

Nawawi, H. (1994). Penelitian Terapan. Yogyakarta: Gadjah Mada University Press.

Rosyida, I., \& Nasdian, F. T. (2011). Partisipasi Masyarakat dan Stakeholder dalam Penyelenggaraan Program Coorporate Social Responsibility dan Dampaknya terhadap Komunitas Perdesaan. Jurnal Transdisiplin Sosiologi, Komunikasi, dan Ekologi Manusia, 53.

Sedarmayanti. (2004). Good Governance Bagian kedua. Bandung: CV Mandar Maju.

Syamsurizaldi, \& dkk. (2018). Dampak Perkembangan Sumber Keuangan Nagari Terhadap Inovasi Program dan Kegiatan Pembangunan Nagaridi Kabupaten Solok Selatan Tahun 20132016. Jurnal Pembangunan Nagari, 8096. 